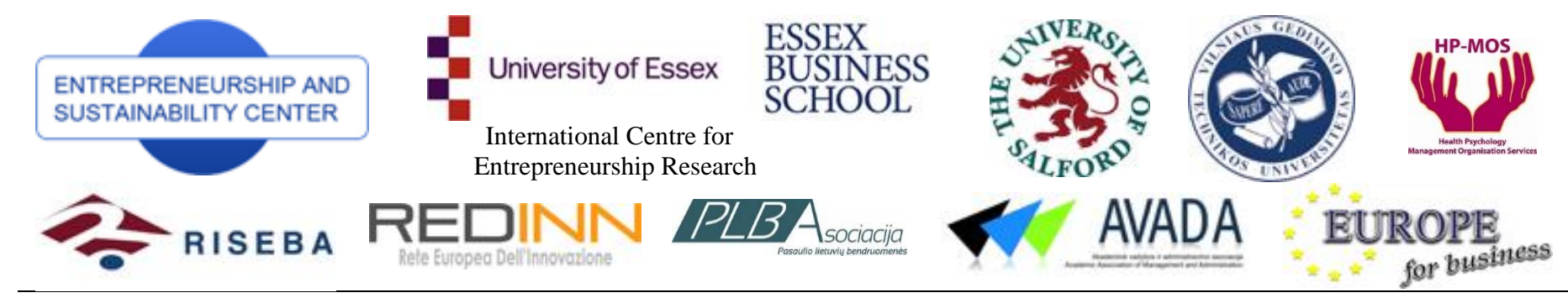

The International Journal

ENTREPRENEURSHIP AND SUSTAINABILITY ISSUES

ISSN 2345-0282 (online) http://jssidoi.org/jesi/aims-and-scope-of-research/

2015 Volume 2 Number 3 (March)

\title{
ENTREPRENEURSHIP CONDITIONS: ENERGY RESOURCES' PRICES AND ENERGY CONSUMPRION PECULIARITIES IN DEVELOPED COUNTRIES ${ }^{1}$
}

\author{
Edouard Dezellus ${ }^{1}$, Letícia Ferreira ${ }^{2}$, Nélson Pereira $^{3}$, Rima Vasiliūnaitė ${ }^{4}$ \\ IIESEG Business School, 3 rue de la Digue 59000 Lille, France \\ ${ }^{2,3}$ Polytechnic Institute of Bragança, Campus de Santa Apolónia - 5300-253, Portugal \\ ${ }^{4}$ Entrepreneurship and Sustainability Center, Čiurlionio 86A, LT-03100 Vilnius, Lithuania \\ E-mails:1,2,3 leticia_voz@hotmail.com ;4rima.vasiliūnaitė@gmail.com
}

Received 15 November 2014; accepted 15 January 2015

\begin{abstract}
In the society man uses energy intensively, human being is completely dependent of energy resources he/she utilizes. Nowadays the society of consumption and production leads to a daily abundant use of available resources on earth. It turns into many forms, such as light, heat, electrical, mechanical, chemical and nuclear. At the end of 20th century, it was almost unanimously agreed, abundant use of these resources have a negative impact on the planet, like the global warming or the greenhouse effect. The reserves of fossil fuels started to show signs of extinction. Due to indicated reasons, the development of many renewable energies have been started. Anyway, a question what energy composition or "mix" is the best, remains open. We raise hypothesis, that energy mix used by a country, depends on availability of particular resources and their prices. Hence, the paper is devoted to analysis of energy resources structure and their prices in four developed countries: France, Japan, USA and Germany. Insights about validity of raised hypothesis are being formulated.
\end{abstract}

Keywords: energy resources, energy mix, energy prices, impact, developed countries, entrepreneurship conditions, competitiveness

Reference to this paper should be made as follows: Dezellus, E.; Ferreira, L.; Pereira, N.; Vasiliūnaitè, R. 2015. Entrepreneurship conditions: energy resources' Prices and energy consumprion peculiarities in developed countries, Entrepreneurship and Sustainability Issues 2(3): 163-170.

DOI: $\underline{\text { http://dx.doi.org/10.9770/jesi.2014.2.3(5) }}$

JEL Classifications: Q40

\section{Introduction}

The industrial era of energy resources began in the late seventeenth century in England, and led to an unprecedented scale exploitation of natural resources of the planet. Before the nineteenth century the human being was available to face the necessities of the time just with muscular strength of animals and of itself, through levers and wheels which there also called natural resources. The strength was the first energy to be founded, after was the coal, oil and natural gas. In that time these sources were the revolution of society. The people started to use the energy resources in small portions that allowed to man use and consume energy in large quantities and this was the symbol of progress (Peres da Silva et al. 2003)

\footnotetext{
${ }^{1}$ The paper was prepared under supervision of prof. Manuela Tvaronavičienè, Vilnius Gediminas Technical University, Sauletekio 11, LT-10223, Vilnius, Lithuania, e-mail: manuela.tvaronaviciene@ vgtu.lt
} 


\section{Short characteristics of energy resources}

The energy resources can be classified in two categories; renewable and non-renewable. The renewable energy is available instantly and almost infinite in the planet. In the other hand, there are some limitations in terms of the amount of energy that can be extracted. This type of energy has different sources, such as Hydropower, there is the use of the water; Geothermal Energy, that use the natural heating inside the planet; Wind Energy obtained by moving air (wind); Solar Energy that is captured by the light that the sun emit and Biomass that is the mass of leaving or recently dead plants and animals, along with their wastes. The main purpose of theses previous sources is to produce electricity. Can be referred that these energies resources has negative impacts an on economic and environmental scale. In a general way consists in big costs for installation of the centrals, some visual, sonorous and air pollution. In the opposite side is the non-renewable energy there his use has an end, in other words his demand is higher than his supply. The principal non-renewable resources are Coal there is carbon with organic and some inorganic compounds; Oil that has a mineral origin and is derived from the processing of organic matter; Natural Gas there is a hydrocarbon in form of methane and some other gases and Nuclear Energy there is created from radioactive minerals like uranium and thorium which produce a huge amount of heat. These resources also can be called as dirty energy, since its use has caused significant damage to the environment and society like destruction of ecosystems, reduced agricultural productivity, acid rain and others.

\section{Energy consumption in developed countries}

The reserves of the different sources of energy are not available everywhere in the same quantity on the surface of the earth. That's why every country must make the best use of the reserves that have. Energy efficiency (intensity) is related to its innovative use (e.g. Dudzevičiūtè, Tvaronavičienè 2011; Dudzevičiūtė 2013; Ala-Juusela et al. 2014; Guruz and Scherer 2014; Cuneo et al. 2014; Barberis et al. 2014; Raudeliūnienè et al. 2014) and is one of factors affecting energy security of each country (Lankauskienè, Tvaronavičienè 2012; Tvaronavičienè 2012; Mačiulis, Tvaronavičienè 2013; Vosylius et al. 2013; Baublys et al. 2014; Raudeliūnienè et al. 2014; Vasiliūnaitė 2014; Grybaitè 2011). Comparison of energy resources consumption in developed countries will be done by taking cases of United States of America, France, Japan and Germany; composition of energy used will be juxtaposed in two different years. All selected countries are economically well developed and have access to different types of sources to produce electricity.

\subsection{France}

This European country has the fifth largest economy and is known throughout the world as a country, which relies on the nuclear power. The consumption of the different energy resources in France is different in 2010 is presented in Figure 1.

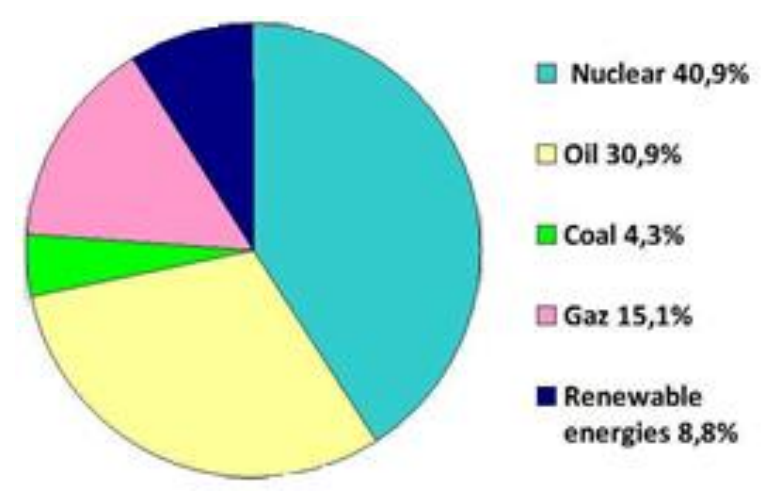

Fig.1. Consumption of France in 2010

Source: Ministry of ecology, sustainable development and energy 
Nuclear energy comprises $40,9 \%$ of whole energy consumption; oil, respectively comprises $30,9 \%$, with coal $4,3 \%$, and gas comprising $15,1 \%$. Renewable energy share in total consumption is $8,8 \%$. France is one of the world's largest nuclear power consumers. It could be pointed out, that nuclear energy as a non-renewable resource has been the most used resource for electricity production. On the other hand, the low percentage of coal in the whole energy mix (recall, just 4,3\%) could be explained by its comparative inefficiency. The structure of energy resources used in 2012, according to the SOeS Key Figures, is the same, so the France maintains the presented pattern of energy consumption.

\subsection{United States of America}

The United States of America could be called the world's the first largest economic power. The structure of different energy resources used in 2011 is the following: oil comprises $36 \%$, coal comprises $20 \%$, natural gas comprises $25 \%$, and renewable energy, respectively, comprises 9\% (Figure 2).

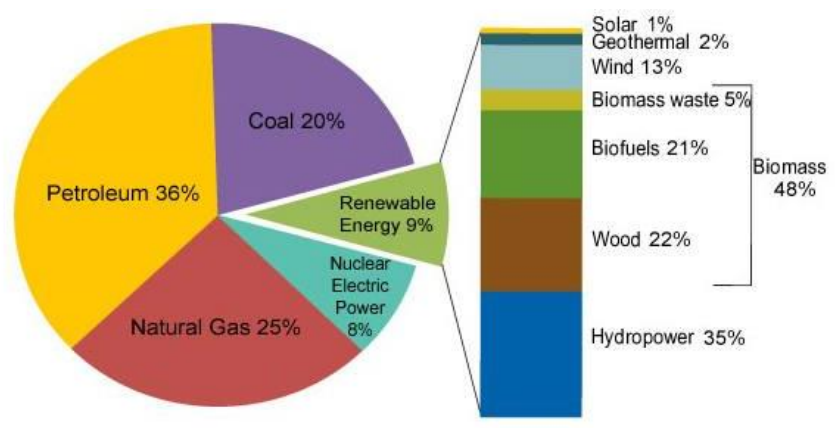

Fig.2. Consumption of USA in 2010

Source: AEI American Enterprise Institute

Attention needs to be drawn to the fact, that nuclear power comprises only $8 \%$. The most consumed resource is oil (36\%). Oppositely, nuclear energy is much less consumed with only $8 \%$ of the global energy consumption. In year 2012, according to the EIA Energy Information Administration, the consumption pattern the same, with $36.48 \%$ for oil, $27.34 \%$ for natural gas, $18.27 \%$ for coal and still $8 \%$ for the nuclear energy (Figure 3). The renewable energy still comprises estimated $9 \%$ of total consumption. As it was already mentioned, USA is maintaining the same structure of different energy sources.

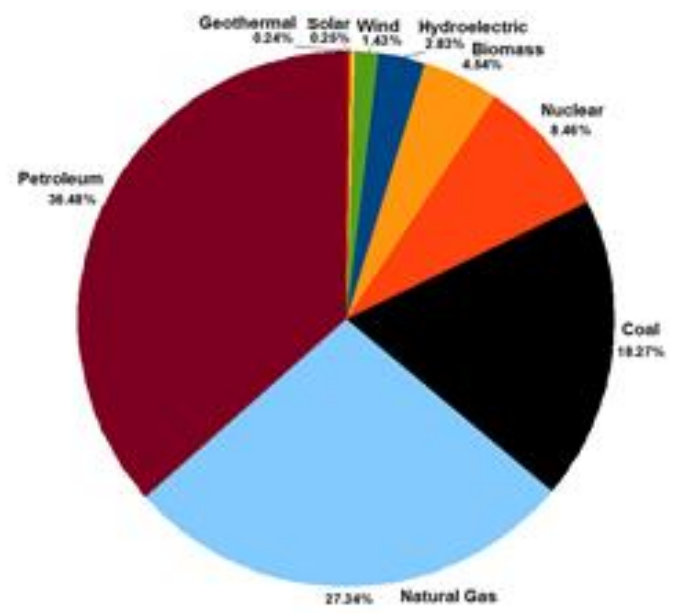

Fig.3. Consumption of USA in 2012

Source: AEI American Enterprise Institute 


\subsection{Japan}

Japan is one of the three the largest economy powers in the world. According EIA International Energy Statistics Japan in year 2010 consumption comprised $42 \%$ of oil overall energy resources consumption, coal, respectively, comprised $22 \%$, natural gas - 18\%, nuclear - 13\%, and renewable energy - 4\% (Figure 4).

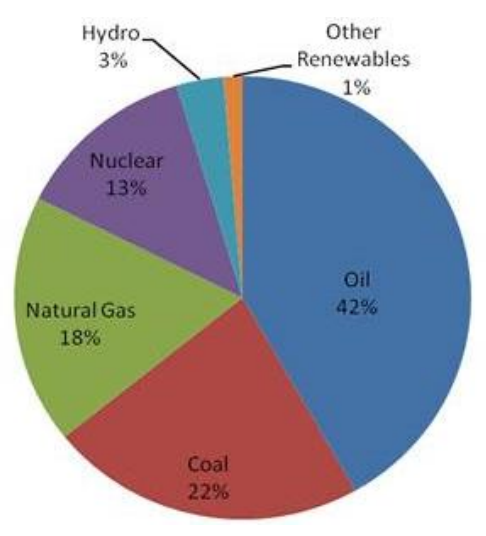

Fig.4. Consumption of Japan in 2010

Source: EIA International Statistics Agency

The most consumed resource is oil. It needs to be mentioned that Japan does not have oil reserves and therefore has to rely on import of this strategic resource. One of the less consumed resources in Japan are other renewable energies like geothermal energy and wind energy (about $1 \%$ of total consumption. In 2012, according to the EIA International Energy Statistics, structure of consumption of the different types of energy resources insufficiently changed (Figure 5).

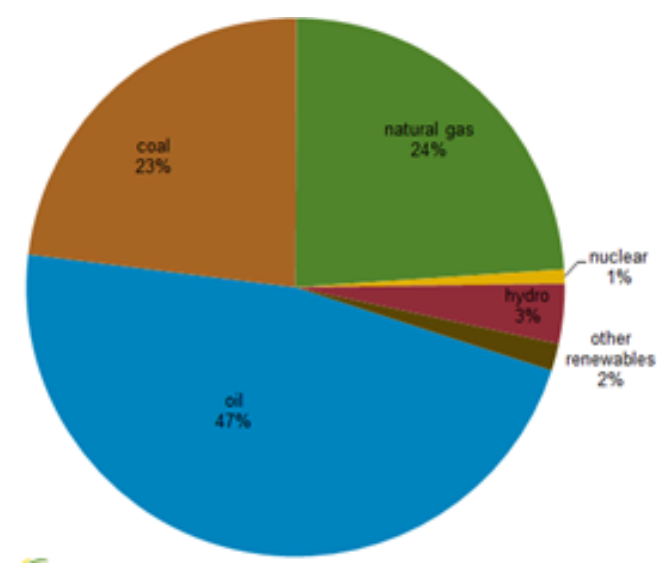

Fig.5. Consumption of Japan in 2012

Source: EIA International Energy Statistics

Juxtapose of statistics for year 2010 and 2012 reflects shrinking of nuclear energy use. The reason is a huge disaster in Fukushima nuclear station that brought negative consequences. So why Japan statistics indicate decrease of the consumption of nuclear power.

\subsection{Germany}

This country is the largest and most powerful national economy in Europe. According to the AEI American Enterprise Institute, in 2010 Germany consume $36 \%$ of oil, $23 \%$ of natural gas, $24 \%$ of coal, $10 \%$ of nuclear 
energy, $1 \%$ of hydropower and finally $6 \%$ of other renewable energies. The most consumed resource in Germany was oil, that it's about $36 \%$ because is the fifth-largest consumer of oil in the world, they import two-thirds of its energy consumed. Germany is also the third-largest consumer of natural gas in the world with $23 \%$ of consumption in this year. The reason why the country have a small quantity of hydropower consumed (1\%), it's because they only adopted the renewable energy recently. In 2012, according to the energy matters euanmearns, the pattern of energy

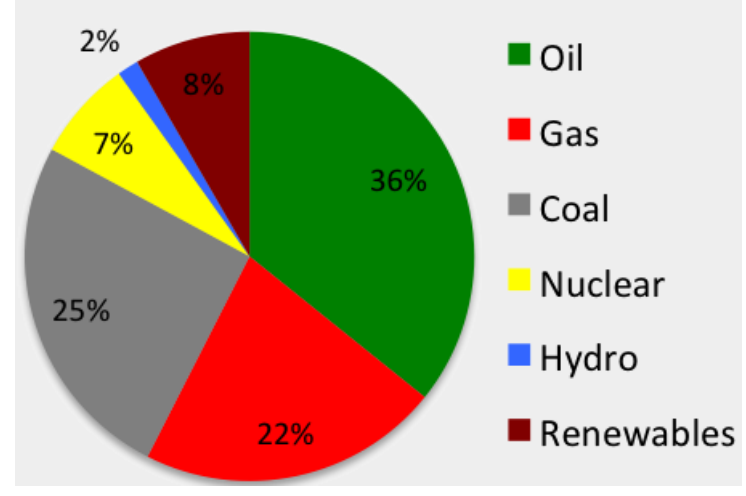

Fig.6. Consumption of energy resources Germany, year 2012

Source: Energy matters euanmearns

consumption changed for very slightly (natural gas comprised $-22 \%$, coal $-25 \%$; nuclear energy $-7 \%$, hydropower - $2 \%$, other renewable energies, respectively, $8 \%$ and a share of oil consumption remained the same, as in year 2010 (Figure 6).

\section{Price, as crucial factor impacting consumption pattern}

Economy of each country is affected by energy efficiency, and, as we assume, price, of energy resources used. Let us take a look at comparison of energy resources prices in countries, selected for our analysis, i.e. France, Japan, USA and Germany. Let us glance at prices of energy resources provided in Table 1 (average of years 2011 and 2012 is being provided).

Let us start our comments with oil. The regular fuel SP95 was chosen as a representative, since it is the most commonly used in all the world. According to the FIA Automobile Club, in 2012 the price (euro per liter) of the fuel SP95 in France is 1,52; in USA 0,77; in Germany 1,56; and in Japan 1,59. It can be concluded that the higher price is in Japan. Let us recall, that Japan does not have reserves of fossil fuels and must import substantial amounts of crude oil. Due to some nuclear problems that Japan suffered in the past, they changed their energy policy and increased the consumption of oil. As the demand increases, ceteris paribus, the price rises too. This phenomenon has negative impact on the competitively of Japan since heavy industry uses a lot of oil. USA has the cheapest price of oil. It is determined by various factors, including tax policy. Way, Any this allows USA to sell their own gasoline to other countries at higher price. Consumption within countries at internationally competitive prices does not push prices of finished goods or services up. France and Germany have rater similar prices of fuel, most likely because of similar governmental approach.

Natural gas price was indicated average price of 2011, provided the World Bank Commodity Price Data. The price is indicated in million per BTU. In France the price is 9,3; in USA is 3,19; in Germany is 10,4 and in Japan, respectively, 16,2. Japan has the higher price because they have small reserves of natural gas so country has to import big amounts of natural gas for inner needs. Japan is the second biggest importer of natural gas in the world. High price needs to be compensated by energy efficiency. This is the way Japan follows. USA, on the contrary, has the cheapest price. Difference between Japan and USA in this respect is considerable. Germany and France has more similarities to Japan than to USA. 
Biomass, nuclear energy, solar energy, hydropower, geothermal energy and wind energy, are resources, which are used for production of electricity. However each resource has different level of availability and affordability (costs) in the different countries and this factor partly causes contrast in prices. The measure is expressed in price for hour in megawatt. The source, which was used is EDF Electricité de France, DLA Piper and European Comission; average data for year 2011 was taken. The next graphic shows the difference between prices through the division of the energy resources to produce electricity. In table 1 the lowest price is presented in red color.

Table 1. Prices of energy resources in selected developed countries

\begin{tabular}{|c|c|c|c|c|}
\hline Prices & France & USA & Germany & Japan \\
\hline $\begin{array}{c}\text { Electricty from } \\
\text { Biomass }(\mathrm{Mw} / \mathrm{h} / \mathrm{\ell}) \text { in } \\
2011\end{array}$ & 43.4 & 81.9 & 70 & 137.8 \\
\hline $\begin{array}{l}\text { Electricty from } \\
\text { Nuclear energy } \\
\text { (Mw/h/€) in } 2011\end{array}$ & 49.5 & 76.1 & 53.5 & 35.1 \\
\hline $\begin{array}{l}\text { Electricty from Solar } \\
\text { energy }(\mathrm{Mw} / \mathrm{h} / \mathrm{k}) \text { in } \\
2011\end{array}$ & 229 & 194.1 & 125 & 280.4 \\
\hline $\begin{array}{l}\text { Electricty from } \\
\text { Hydropower } \\
\text { (Mw/h/€) in } 2011\end{array}$ & 75 & 67.1 & 81.3 & 173.1 \\
\hline $\begin{array}{l}\text { Electricty from } \\
\text { Geothermal energy } \\
\text { (Mw/h/€) in } 2011\end{array}$ & 31.8 & 38.24 & 48.2 & 187.3 \\
\hline $\begin{array}{l}\text { Electricty from wind } \\
\text { energy }(\mathrm{Mw} / \mathrm{h} / \mathrm{\ell}) \text { in } \\
\qquad 2011\end{array}$ & 82 & 63.86 & 100 & 158.2 \\
\hline
\end{tabular}

Sources: EDF Electricité de France, DLA Piper and European Comission

It can be concluded that Japan has the higher price of electricity, produced by using biomass, solar energy, hydropower, geothermal energy and wind energy. During 30 years Japan developed cheap efficient nuclear factories, but with Fukushima accident in 2011, the country they decided to reduce their production of nuclear energy. Anyway nuclear power for energy production purposes is still being used. Considering wind energy, Japan doesn't have good places to catch the powerful wind to produce this type of energy. France and Germany are the two largest producers of renewable energy in Europe. France is cheaper than Germany in almost all that resources, except solar energy. Besides that France is the cheapest in biomass because the country has a lot of agriculture power and also geothermal energy because it's possible to find geothermal deposits in many parts of its territory. Germany is the cheapest in solar energy because industry of photovoltaic panel is very powerful. It is the first producer of solar energy ( $76.8 \%$ of world production). Finally, USA is the most expensive in nuclear energy because of political priorities' reasons (focus on in fossil fuels is being put). Also it can be concluded that USA is the cheapest in hydropower and wind energy because they are developed in these two resources and use that electricity for domestic consumption.

Finally, about coal. It is presented in average price of year 2012. The price is indicated in euros per ton: for France it is 64,3; for USA - 55,8; for Japan - 67,9 and for Germany, respectively, 67,8. The cheapest price belongs to USA because they have a lot of reserves and use it for production of electricity. It have been increasing through years and it been used since 1882. While Germany, France and Japan have more or less equal prices of coal.

\section{Conclusions}

Energy resources use patterns, energy consumption peculiarities in different countries depends on variety of factors, such as, level of development of the country, its size in terms of population, the levels of consumption and production of private and public sectors and also the fluctuation between supply and demand, economic policy, and many other factors. Anyway, countries can be divided in two categories, like the ones with low reserves of fossil energy and the others with high level of reserves. Countries with low reserves of fossil resources need to 
import more in order to produce and to be more competitive. On the other hand, import of energy resources diminish international competitiveness of a country, unless it is extremely energy efficient, as Japan. About the other category of countries which have high reserves of fossil energy they have more competitiveness because they export must more than import. I could be concluded that among the four analyzed countries, United States of America, could be recognized as being in the most favorable position, because it has the lowest prices of all energy resources. In order to develop sustainable futures, entrepreneurs have to be aware and take into account countries difference in field of energy prices and energy consumption patterns.

\section{References:}

AEI American Enterprise Institute (online). Available at: <http://www.aei.org/publication/the-costs-of-german-fear-energy-fact-of-theweek>.

Ala-Juusela, M.; Short, M.; Shvadron, U. 2014. Tools to support sustainable entrepreneurship in energy positive neighbourhoods, Entrepreneurship and Sustainability Issues 2(2): 49-59. DOI: http://dx.doi.org/10.9770/jesi.2014.2.2(1)

Barberis, S.; Di Fresco, L.; Santamaria, V.A.; Traverso, A. 2014. Sustainable entrepreneurship via energy saving: energy harvester exploiting seebeck effect in traditional domestic boiler, Entrepreneurship and Sustainability Issues2(2): 86-97. DOI: http://dx.doi.org/10.9770/jesi.2014.2.2(4)

Baublys J.; Miškinis V.; Konstantinavičiūtė I.; Lekavičius V. 2014. Aspirations for sustainability and global energy development trends, Journal of Security and Sustainability Issues 3(4): 17-26. DOI: http://dx.doi.org/10.9770/jssi.2014.3.4(2)

BP Statistical Review of World Energy (online). Available at: <http://www.bp.com/content/dam/bp/pdf/Energy-economics/statisticalreview-2014/BP-statistical-review-of-world-energy-2014-full-report.pdf $>$.

Cuneo, A.; Ferrari, M.L.; Traverso, A.; Massardo, A.F. 2014. Sustainable district development: a case of thermoeconomic optimization of an energy hub, Entrepreneurship and Sustainability Issues2(2): 74-85. DOI: http://dx.doi.org/10.9770/jesi.2014.2.2(3)

DLA Piper (online). Available at: 〈https://www.dlapiper.com/en/japan/sectors/energy $>$.

Dudzevičiūtè, G. 2013. Energy intensity in the Lithuanian manufacturing sector, Journal of Security and Sustainability Issues 3 (2): $77-85$. http://dx.doi.org/10.9770/jssi.2013.3.2(6)

Dudzevičiūtè, G.; Tvaronavičienè, M. 2011. Measurement framework of innovation activity: theoretical approaches' analysis, Journal of Security and Sustainability Issues 1(1): 61-73. DOI: http://dx.doi.org/10.9770/jssi.2011.1.1(6)

EIA International Statistics Agency (online). Available at: 〈http://www.eia.gov/countries/cab.cfm?fips=JA 〉 .

Energy Matters (online). Available at: < http://euanmearns.com/germany-energiewende-kaput/>.

EDF Electricité de France (online). Available at: 〈http://france.edf.com/france-45634.html〉.

FIA Automobile Club (online). Available at: 〈http://www.automobile-club.org/files/SeDeplacer/prix_carburants.pdf?2014-11-16 >.

Grybaite, V. 2011. Towards measurement of sustainable development: systems of indicators, Journal of Security and Sustainability Issues 1(1): 17-24. DOI: http://dx.doi.org/10.9770/jssi.2011.1.1(2)

Guruz, R.; Scherer, R. 2014. Sustainable energy entrepreneurship through architectural design: a key point controlled method,Entrepreneurship and Sustainability Issues2(2): 60-73. DOI: http://dx.doi.org/10.9770/jesi.2014.2.2(2)

Lankauskienė, T.; Tvaronavičienè, M. 2012. Security and sustainable development approaches and dimensions inn the globalization context, Journal of Security and Sustainability Issues 1(4): 287-297. DOI: http://dx.doi.org/10.9770/jssi.2012.1.4(5)

Mačiulis, A.; Tvaronavičienè, M. 2013. Secure and sustainable development: Lithuania's new role in taking the Presidency of the EU, Journal of Security and Sustainability Issues 3(2):5-13. DOI: http://dx.doi.org/10.9770/jssi.2013.3.2(1)

Ministère de l'écologie, du développement durable et de l'énergie [Ministry of ecology, sustainable development and energy] (online). Available at: 〈 http://www.developpement-durable.gouv.fr/Prix-du-gaz-et-de-l-electricite-en.html〉. 
Peres da Silva, E.; Carlos Camargo, J.; Sordi, A.; Resende Santos, A.M. 2003. Available on the Internet:

<http://www.multiciencia.unicamp.br/art04.htm $>$.

Raudeliūnienė, J.; Tvaronavičienè, M.; Dzemyda, I. 2014. Towards economic security and sustainability: key success factors of sustainable entrepreneurship in conditions of global economy, Journal of Security and Sustainability Issues 3(4): 71-79. DOI: http://dx.doi.org/10.9770/jssi.2014.3.4(7)

Raudeliūnienė, J.; Tvaronavičienė, M.; Dzemyda, I.; Sepehri, M. 2014. Sustainable entrepreneurship through energy stewardship: role of values and behavioral patterns, Entrepreneurship and Sustainability Issues 2(2): 107-117. DOI: http://dx.doi.org/10.9770/jesi.2014.2.2(6)

Tvaronavičienė, M. 2012. Contemporary perceptions of energy security: policy implications, Journal of Security and Sustainability Issues 1(4): 235-247. DOI: http://dx.doi.org/10.9770/jssi.2012.1.4(1)

Vasiliūnaite, R. 2014. Sustainable development: methodological approaches toward issues, Journal of Security and Sustainability Issues 3(3): 69-75. DOI: http://dx.doi.org/10.9770/jssi.2014.3.3(6)

Vosylius, E.; Rakutis, V.; Tvaronavičienè, M. 2013. Economic growth, sustainable development and energy security interrelation, Journal of Security and Sustainability Issues 2(3): 5-14. DOI: $\underline{\text { http://dx.doi.org/10.9770/jssi.2013.2.3(1) }}$

Edouard DEZELLUS - IESEG Business School, France. International student, who took a course "Comparative economics" taught by professor Manuela Tvaronavičienè at Vilnius Gediminas Technical University, Faculty of Business Management during fall semester of year 2014.

Letícia FERREIRA - Polytechnic Institute of Bragança, Portugal. International student, who took a course "Comparative economics" taught by professor Manuela Tvaronavičienè at Vilnius Gediminas Technical University, Faculty of Business Management during fall semester of year 2014.

Nélson PEREIRA - Polytechnic Institute of Bragança, , Portugal. International student, who took a course "Comparative economics" taught by professor Manuela Tvaronavičienė at Vilnius Gediminas Technical University, Faculty of Business Management during fall semester of year 2014.

Rima VASILIŪNAITÉ, researcher at Entrepreneurship and Sustainability Center, Vilnius, Lithuania. Research interests: sustainable development, energy security, productivity accounting, entrepreneurship.

This is an open access journal and all published articles are licensed under a Creative Commons Attribution 4.0 International License 